\title{
STATE, EUROPEAN INTEGRATION, AND GLOBALIZATION. NEW CHALLENGES FOR CONSTITUTIONALISM
}

Stelio Mangiameli ${ }^{1}$

\section{Abstract}

The essay takes into consideration the current relations between the State, European integration and globalization, with reference to the principles of constitutionalism. The principles of constitutionalism, such as the division of powers, the guarantee of the fundamental rights, federalism and representative democracy, are examined in the light of modern and contemporary statehood, which shape the constitutional State. The processes of integration of financial markets and modern technologies, as well as economic crises, have impacted on the constitutional State and revealed the insufficiency and inadequacy of State institutions in terms of size and capacity. Hence the idea of the constitutionalisation of Europe by the Member States as a remedy to reaffirm the safeguarding of fundamental rights and the guarantee of a democracy of proximity. Furthermore, international processes have accelerated the transition to a global market, which has undermined the sovereignty of States and their political weight. However, in such a context, States can only recover their role if the principles of constitutionalism are applied in the international order, so that the sovereignty of States opens up towards an international order which is characterized by inter-state cooperation and promotion of universal principles.

\section{Keywords}

Constitutionalism. State. European integration. Globalization. Division of powers. Fundamental rights.

\section{Summary}

1. The features of Constitutionalism. 2. Constitutionalism and the State form: federalism, democracy and economy. 3. The supranational and international dimension. 4.Technology and global economy. 5. The crisis of State sovereignty and the loss of control of national wealth. 6. The questions to be answered and the necessary presence of the State. 7. Globalization and European integration: the need to constitutionalise Europe. 8. The constitutionalisation of international processes.

${ }^{1}$ Full Professor. Law Faculty. Teramo University - Italy. 


\section{THE FEATURES OF CONSTITUTIONALISM}

Jurists usually offer descriptive and normative analyses of some previously delimited issue. The limits, or boundaries, constraining the relationships among globalization, European integration, State, and constitutionalism, however, are so hard to define that discussion risks superficiality and predictability. I will try to avoid those pitfalls.

Merely attempting to define the key terms 'constitution' and 'constitutionalism'3 immediately illustrates the difficulty. These terms are linked to the events that led, at the end of the eighteenth century, to the birth of two cardinal principles: the recognition of individual, personal rights and the principle of the division of powers, both undergirding the principle of legality of State action. ${ }^{4}$

The first formulation of these two principles appeared in Article 16 of the Declaration of the Rights of Man and of the Citizen of 1789: 'Any society in which the guarantee of rights is not assured, nor the separation of powers determined, has no Constitution'. The term 'constitution' was not taken in a theoretical sense, as that which constitutes any order in the form of a State,

${ }^{2}$ Based on the teaching of JELLINEK 1922, 505: 'Die Verfassung des Staates umfasst demnach in der Regel die Rechtssätze, welche die obersten Organe des Staates bezeichnen, die Art ihrer Schöpfung, ibr gegenseitiges Verhältnis und ibren Wirkungskreis festsetzen, ferner die grundsätzliche Stellung des einzelnen zur Staatsgewalt' ('The Constitution of the State therefore generally includes the legal provisions that describe the highest organs of the State, the type of their creation, their mutual relationship and their sphere of activity, as well as the fundamental position of the individual regarding State power', my translation).

3 Hamilton 1937, 255; Beaud 2003, 133; Casper 1986, 473; Preuss 1998, 618; "Konstitutionalismus", in RITTER et al 1989, 1005.

4 On the foundation of the principle of legality see, first, Mayer 1895, 67. 
but in the sense of precise contents that the constitution should have had. ${ }^{5}$ This model of constitution, so important and situated in a declaration that still has normative value, at least in the French legal system, has informed constitutional thought in the nineteenth and twentieth centuries, as shown in the constitutions of western States. ${ }^{6}$

These constitutions manifest two distinctly recognizable parts, the first relating to the rights and duties of citizens and the second relating to the State system. This structure of the constitutions of the first (Weimar constitution) and of the second post-war period (Italian Constitution and Grundgesetz) also influenced the other constitutions that were born in Europe in the recent past (such as the Spanish and the Portuguese ones) and correspond to the original model of constitutionalism.

However, beyond these two elements, which we could define as originating and which over time have been to some extent maintained, albeit with the changes required by the affirmation of the welfare state, it is necessary to add at least two other features, in order to understand the essence of what today we define as constitutionalism: one, the federal principle, raising contemporary issues not only for the State within itself, but also its external relations; the other, which established itself throughout the nineteenth and then the twentieth century, through the victory of parliamentary representation, first, and then universal suffrage as a democratic principle. ${ }^{7}$

Federalism is an ancient institution that dates back to Roman law, and was perhaps known even before, in the form of the stable alliance of Etruscan cities. However, in the modern sense, it is linked to American history, particularly to the Declaration of Independence of July $4^{\text {th }}, 1776$ and to the

5 The constitution in the historical-political sense, according to the meaning of Crisafulli 1970; it is a teaching common to the western tradition, see MCILWAIN 1947; WORMUTH 1949; WhEARE 1951; Vile 1967; MATTEUCCI 1976; MANSFIELD 1985, 323-326.

${ }^{6}$ SCHMITT $1928,37$.

7 SARTORI 1993; SARTORI 1957. 
formation of the American Constitution of $1787 .{ }^{8}$ American federalism designs a State other than the unitary one that emerges with the French State model, which was heir of the great European national monarchies, and affirms a theory of the State where, alongside the aggregation from below, with the delegation of powers to a higher entity, ensuring decentralization of functions. So, there are simultaneously two political entities with distinct powers that are recomposed as a system in a unit that is defined as a 'federal State' ('dual federalism'). ${ }^{9}$ Federalism, therefore, is connected to the principle of division of powers, the former would determine a horizontal division, while the latter would operate a vertical division, recognizing multiple levels and creating a sort of limited government based on the territory. ${ }^{10}$

The democratic principle, the other characteristic that typifies modern constitutionalism, is linked, in the Western tradition, to the affirmation of individual subjectivity and to the phenomena that this has produced, such as, for example, the secularization of the State. It is based on the 'rule' that the subjects, called to legitimize collective decisions, are the same who will have to suffer their consequences. ${ }^{11}$ This principle is linked, in modern systems, to the canons of representation, as opposed to direct popular participation, and has gone through the evolution of the constitutional State. ${ }^{12}$ Its full accomplishment took place with the affirmation of universal suffrage and, in order to understand that it is a recent acquisition, one can consider that, in Italy, this is only achieved with the election of the Constituent Assembly and the institutional referendum of June $2^{\text {nd }}, 1946$.

${ }^{8}$ HAMILTON et al 1787.

${ }^{9}$ See Supreme Court US, Gibbons v. Ogden, 22 US 1 (1824).

10 ACKERMANN 2000, 634-729.

11 Esposito 1954, 1.

12 ZANGARA 1983, 193-252. 


\section{CONSTITUTIONALISM AND STATE FORM: FEDERALISM, DEMOCRACY AND ECONOMY}

These four elements are located within a single context represented by the State. The container of constitutionalism is, therefore, the State, and there cannot be any other. The same evolution of the federal principle, which binds different political entities together, brings them to synthesis within a (federal) State and, of course, in a legal system the union between the nature of the State and the federal idea creates problems. In fact, the unifying force inherent in statehood tends to reduce federal substance to mere form, with a real impact on the decentralized and articulated nature of the system. ${ }^{13}$

Already at the beginning of the second half of the last century, an eminent German constitutionalist, Konrad Hesse, spoke of the 'unitary federal State'. ${ }^{14}$ Hans Kelsen himself, in describing Austrian federalism, in his commentary on the 1920 Constitution, ${ }^{15}$ speaks of it as a decentralized unitary State and Costantino Mortati, when he analysed Italian regionalism by comparing it with the federal system, in his Institutions of public law, ${ }^{16}$

13 SCHMITT 1928, 389, underlines this aspect, where he refers to the union of democracy and federal State organization, which would lead to a peculiar and autonomous type of State organization, to the federal State without a federal foundation. Schmitt writes: 'Scheinbar ist das ein widerspruchsvoller Begriff. Doch handelt es sich bei dem bundesstaatlichen Charakter um einen Verfassungsbestandteil, in welchem au seiner früheren bundesmäßigen Organisation Elemente in die neue Staatsform übernommen sind. Politische Gebilde wie die Vereinigten Staaten von Amerika oder das Deutsche Reich der Weimarer Verfassung sind kein Bund mehr' ('Apparently this is a contradictory concept. Instead, it is a constitutional element in the federal State character, in which elements from a previous federal organization are taken up in the new form of State. Political formations such as the United States of America or the German Reich of the Weimar constitution are no longer a federation' my translation). The reference to Federalist, paper No. 49, 1788 is also very interesting.

14 HESSE 1962.

15 KELSEN 1920; KELSEN 1923.

16 MORTATI 1976, 991. 
affirmed that there is no appreciable difference between regionalism and federalism: these are equally unitary systems which are distinguished, if anything, according to the level of decentralization.

Furthermore, a similar discourse places the democratic principle which, in permeating the constitutional State, also supports a form of unification which harms the idea of plurality of levels of government. Indeed, the power to make binding public decisions, ${ }^{17}$ according to their respective competences, weakens for regional and local governments.

To some extent, it can be said that within the modern State, various myths operate against the institutional and social pluralism, such as the nation, the revolutionary class, and popular sovereignty; these myths, however, confront themselves only with the presence of the individual. The idea of eliminating the various bonds of the individuals within the State comes from Enlightenment, and acts as a catalyst for the unifying force of representative democracy, which transforms citizens into voters and reduces participation in the vote for a parliament. In its depth acts the secular projection of the reform, for which, just as the believer is placed before God, the citizen finds himself vis-à-vis the State without any intermediation. ${ }^{18}$ The formation of the 'general will', then, would make other public wills, which would represent limited and limitable forms of autonomy, subordinate and insignificant. $^{19}$

This structure of the modern State finds in the development of the capitalist economy a powerful factor that feeds its ability to unify. Already Adam Smith (1723-1790) had clearly highlighted, while speaking of the wealth of nations, the connection that exists between these two elements. The State was born as the protector of national wealth, through its duties for defence and justice, and its role as a public works developer and manager of public

${ }^{17}$ ELSTER and Slagstad 1988.

18 KAISER 1956, 63.

${ }^{19}$ ROMANO $1950,351$. 
institutions. State sovereignty over the economy undoubtedly manifests itself in many ways, the most significant of which lies in the State's ability to determine the values of trade: monetary sovereignty represents the synthesis of the State's ability to regulate the market, together with the provision of restrictions on imports, the establishment and collection of taxes, and the implementation of budgetary policy (and public debt).

However, in reality, this intertwinement between State and capitalist economy is not a serene union. Historically, it never was: on the one hand, the capitalist economy both tended to take revenge on the State and, in its cyclical development, led to moments in which it asked to reduce the State's ability to regulate the economy, in the name of economic freedoms and of the autonomous functioning of the market (laissez faire principle); on the other hand, however, just as cyclically, the State's capabilities were invoked for interventions in moments of crisis (principle of protectionism), thus showing the limits of the liberal idea of the invisible hand. ${ }^{20}$

The evolution that led to the 1929 crisis and the responses to it in terms of public intervention ${ }^{21}$ are exemplary with reference to the elaboration of a

20 See GALGANO 1974.

21 With the crisis of 1929, production, employment, incomes, wages, consumption, investments, and savings, in other words, all those economic quantities whose performance normally characterizes the progress, or the regression of a country's economy were worldwide reduced. What made this crisis unique was that the contraction in economic activity occurred as quickly and radically as never before. In this regard, it is sufficient to consider that on an international level, the crisis manifested itself with the contraction of trade (imports-exports: from 68.606 million dollars-gold in 1929 to 24.175 in 1933), which led, as a first consequence, to the adoption of customs duties on foreign products, especially cereals, with the consequent fall in cereal exports for the poorest countries (especially in Eastern Europe). The commercial crisis, however, could not fail to have repercussions on the financial crisis first and then on the monetary crisis. This led to the bankruptcy of the major European banks (Credit Anstalt of Vienna, Dresdner Bank and Darmstadter und National Bank) with repercussions on the London market, where all shortterm loans were recalled, for which a previously unimagined weakness emerged, as the non- 
State presence in the economy. ${ }^{22}$ In fact, Arthur Cecil Pigou (1877-1959) elaborates his thesis of the welfare State, ${ }^{23}$ while John Maynard Keynes (1883-1946) formulates the theory of money according to the principle of public spending, for which the State creates an added demand, restarts the

flow of money resulted in the inability to return also because the capital to be repaid had been invested in the medium and long term. The request for a moratorium in September 1931, by the Bank of England and the Labor government, led, on the one hand, to the suspension of payments (with the consequent further collapse of creditors) and, on the other hand, to a considerable devaluation of the sterling $(30.68 \%$ against the dollar and the abandonment of the Gold Standard). The financial earthquake ended up involving all the world currencies. One has to consider, moreover, that there is no such thing as a crisis (stock exchange or financial, banking or monetary, commercial or industrial), which does not have massive ripple effects, DE ROSA 1979).

According to the data of the League of Nations, in fact, unemployment exceeded 25 million units in 1932, to which one must add the millions of agricultural workers and peasants who, if not unemployed, were, almost everywhere, only partially employed. Unemployment, in any case, was aggravated by deflationary policies, which were adopted to avoid consequences on the State budget and were based on the reduction of wages, on the increase in direct taxation (also on wages), and on the drastic reduction of public expenditure (see, for example, the work of the Brüning government in Germany). The transition from the social crisis that followed the deflationary measures to the political crisis was short; it is, in fact, to the discontent it provoked that Hitler's first success in Germany in the elections of July 1932 must be attributed, success that was renewed and increased in the new elections of November, even if, in the meantime, starting from early September, the so-called 'von Papen plan' had tried to give numerous stimuli to domestic demands, and had favored industrial recovery with the reduction of the discount rate to $4 \%$ and some credit facilities.

${ }^{22}$ Such presence of the State is contrary to the policy of containing public expenditure and safeguarding the value of the currency (promoted by president Herbert Hoover), which is to be considered one of the main causes of the huge unemployment worldwide. The popular push in favour of the presence of the State in the economy, in the United States, in the framework of the presidential elections of November 1932, led to the defeat of Hoover and the victory of F. D. Roosevelt, who promoted the New Deal, DE RosA 1979. 23 PigOU 1932. 
economic cycle and, in this way, implements production, consuming, savings, investment and employment. ${ }^{24}$

On a strictly legislative level, with the intervention of the State in the economy, some significant trends emerged, which determined the evolution of the theory of federalism towards forms of unification. The original federal State, built by aggregation of previous States, was characterized as 'dual federalism', for which there would be two perfectly divided spheres: in each of the two areas, the legislative, executive, and judicial authorities would enjoy total autonomy and an almost independent status. The hypothesis that conflicts between these two levels may arise was initially underestimated.

With the development of the problems related to economy, in particular with the crisis of 1929, the constitutional theory of federalism undergoes a profound transformation. Dual federalism is abandoned, firstly by politicians (e.g. the famous New Deal) and, secondly, by the American Supreme Court, which pronounced a series of judgements of open support to the new course. ${ }^{25}$ The 'new course' was based on two concepts that were not directly compatible with each other, even though both promoted an expansion of federal power: cooperative and competitive federalism. In the first case, the relationship between Member States and federation is no longer about separation, but about collaboration within a unitary project; this determines a series of interferences between State and federal competences which determines an imbalance of power that benefits the latter. In the case of competitive federalism, in the second case, there is an application of the principle of competition within the federal principle, based on the drive to

${ }^{24}$ KEYNES 1936.

${ }^{25}$ Supreme Court US, West Coast Hotel Co. v. Parrish, 300 US 379 (1937); National Labor Relations Board v. Jones \& Laughlin Steel Corporation, 301 US 1 (1937); Steward Mach. Co. v. Davis, 301 US 548 (1937); United States v. Darby, 312 US 100 (1941); Wickard v. Filburn, 317 US 111, 128-129 (1942); Oklahoma v. United States Civil Service Commission, 330 US 127 (1947). 
compete by the various Member States in order to obtain a greater amount of federal resources for their own territory; moreover, in this way the federation is allowed to affect the constitutional autonomy of the Member States.

\section{THE SUPRANATIONAL AND INTERNATIONAL DIMENSION}

However, the economic crisis, in addition of involving a concentration of power at the detriment of its division as happens in the case of the federal State, determined another phenomenon. In fact, from the effects of the crisis it also emerged that, in order to make the economy progress, the State, as an institution capable of offering a unitary and synthetic framework, starts to become insufficient in size and capacity.

The idea of European integration, which took its first steps on the basis of the need to consolidate peace in the old continent, came into effect through a supranational power to govern the economy. The economic theory underlying the European process was developed in the 1930s by the School of Freiburg, ${ }^{26}$ in parallel with the Keynesian theses, and became standard with the Treaty establishing the European Economic Community. ${ }^{27}$

It is the idea of the regulated market. The market is the place where values must be formed and exchanged, but for this to happen, it cannot be totally

26 HAYEK 1939, 131-149.

27 The Freiburg School maintains that the commitment of the State must be minimal, but strong enough to protect the market and the whole economy from undue pressure from power groups; a power, therefore, such as to ensure that the market is correct, and 'fair', as the Anglo-Saxons would say, and that gives to each individual opportunities, in order to allow and facilitate social integration and political stability, see GOLDSCHMIDT 2005; VATIERO 2010, 689-707. 
abandoned to itself. On the contrary, it must be regulated, not so much in its functioning, as in its possible degenerations, which could derive from the formation of concentrations capable of dominating economic and political relations to the detriment of competition and consumers.

To achieve the purposes of the regulated market, a supranational entity managed by the States is created and endowed with an authority that guarantees the effectiveness of competition, also with respect to the action of the States themselves. The instrument with which this supranational entity has been equipped and acts is a directly effective law within the Member States: a law of general validity and supervised by a common judge capable of asserting its legal force. ${ }^{28}$ This law is not an international law, and at the same time it is not part of the national legal order. Despite its distinction from the laws of the Member States, it adopts a federal-type institutional scheme, based on the principle of supremacy of the American constitution.

On this basis, a dimension is formed that goes beyond the independence of the Member States and whose federal configuration, over time, has evolved, not only due to the growth of the tasks, no longer limited to the simple economic sphere, and for the foundation of a common European citizenship, but especially in regard to the questions it has been able to bring about on the issue of national sovereignty, compared to the supranational dimension. European integration, in this context, has gradually become constitutionalized, assuming a peculiar (and in part unpublished) subjectivity, in the context of international law.

For these reasons it can be said that European integration, which has certainly not a global, but a regional dimension, was born through the control of coal and steel production to avoid subsequent wars. Moreover, the European integration goes beyond such interests, as it is based on a

${ }^{28}$ MANGIAMELI 2001. 
specific tradition, precisely the European one, and is aimed at recovering the identity of the old continent, as well as the idea of Europe itself. ${ }^{29}$

From an international point of view, however, the phenomena that the development of the economy produces are even more complex, even if they also originate in the economic crisis of 1929.

Before the Great War, the world had already reached a considerable rate of good exchanges, which the wartime events collapsed and hence the onset of the economic crisis. When symptoms of recovery were recorded in 1933, with industrial production growing compared to the previous year and with employment generally increasing, reconstruction of the world trade system was also attempted.

However, the World Economic and Monetary Conference, which opened in London in June 1933, after a long preparation, sanctioned the effective crushing of the world market, marking the definitive failure of any attempt at international collaboration. ${ }^{30}$

${ }^{29}$ CHABOD 1961.

30 The Conference had clashed over the question of whether the various currencies had to be stabilized and if the 'return to gold' as the basis of the monetary system and of international transactions had to be re-established, and ended with the deliberate devaluation of the dollar (10\%), firmly pursued by Roosevelt and France's stubborn defence of gold. Three main blocs with different economic policies emerged from the Conference: 1) the dollar area (Roosevelt wanted to use the devaluation to reduce domestic debt and increase the purchasing power of the agricultural classes, so that they could intensify the purchases of industrial products, and therefore actively contribute to the recovery); 2) the sterling area (Great Britain explicitly stated that monetary policy should not be aimed at maintaining the stability of foreign exchange rates, but only at ensuring abundant and cheap credit); 3) the golden block: France, Belgium, Italy, Switzerland, the Netherlands and Poland (these countries aimed to guarantee the stability and solidity of the currency, pursued through the balance in the State budgets and in the balance of payments, even at the cost of implementing deflationary policies). 
Thus, 1933 became the crucial year for the world, because the foundations for the new world conflict were laid. The events that determined the tragedy of history are, above all, three: the fall of the dollar, Hitler's rise to power, and State interventionism in the economy. ${ }^{31}$ Thus, at the end of the Second World War, the world found itself, for different historical reasons and in the presence of profoundly different political bases, in front of closed economic systems, in every sense, on the horizon of the State: the prevailing market was governed by the State and the subjects of the economy were State entities.

However, thanks to peace, international trade was gradually reorganized, both with the renegotiation of international agreements for the movement of goods and with the creation of international economic institutions. ${ }^{32}$ Thus, the market takes an increasingly international shape, which, however,

31 State interventionism first assumed the characteristic of an increase in public spending. The reduction in public spending had been one of the cornerstones of the deflationary policies adopted in the first phase of the crisis. Now, in the last phase, public spending returned to many countries, but with significant differences between them. Among the effective forms of interventionism there was also assistance in favour of particularly depressed industries, both with subsidized loans and with interventions aimed at improving their internal organization. Everywhere, export industries were encouraged, but in some countries, as for instance in Italy, State intervention reached even more direct forms. In Italy, after the establishment of the I.M.I. (Italian Mobiliare [Chattel] Institute), in 1931, the I.R.I. (Institute for Industrial Reconstruction) was subsequently established in January 1933. With the I.M.I. and especially with the I.R.I. Italy aimed at once, at financial disinvestment, on the one hand, and at the management and production reorganization of the industrial system, on the other hand, DE ROSA 1979.

32 In this context, it should be recalled that global trade, at the international level, is now largely regulated; the possible interventions were governed by the Arrangement on guidelines for officially supported export credits, known also as the Consensus (a gentlemen agreement to which the industrialized countries adhered and which the Community implemented through a Decision), as well as by the Agreement on subsidies and countervailing measures of the Word Trade Organization which, in prohibiting export subsidies, was without prejudice to public initiatives compliant with the Consensus. 
will really become global only after the fall of the Berlin Wall (1989), the end of Soviet ideology, and with the conversion of China to capitalism without liberalism.

\section{TECHNOLOGY AND GLOBAL ECONOMY}

The world volume of trade in goods reached before the Great War was equalled (and surpassed) only in the late 1960s, but the internationalization of the economy took on a completely different physiognomy than that of the States of late 1800s. In fact, the economic processes will themselves be correlated to the development of new technologies, which have been able to modify the circulation of financial capital and to overcome the boundaries of the Nationalökonomie, to implement a new lex mercatoria and to allow the most recent and complex phenomenon of relocation of productive activities.

The engine of this transformation is given by the idea of a network, which, with the contraction of the time-space dimension, determines not only the overcoming of the national economy, but also that of the State, the territorial authority par excellence. ${ }^{33}$ As has been rightly observed 'whatever moves with the speed approaching the velocity of the electronic signal, is practically free from constraints related to the territory inside which it originated, towards which it is aimed or through which it passes on the way' $^{34}$

${ }^{33}$ Capital has no fixed abode and financial flows are largely out of government control; thus, many of the levers of economic policy no longer work, see AMATO MANGIAMELI 2004.

34 BAUMAN 1998, 55. 
If the speed of movement of goods is in any case delimited by their physicality, the speed of financial exchanges is such as to be globalized in a complete sense, ${ }^{35}$ but the internationalization of such factor has complex global consequences, also because it operates on profoundly different realities, especially because of the inequality, which allows to make greater profits by using the human factor in an extreme way. If everyone were paid in the same way, there would be no reason to move businesses or relocate production. This happens because the lack of rights, in a part of the world, allows for a less fair and upright treatment of men; and this is how the relocation of a company creates two poverties: the first in the place where the company is removed, the second in the place where it settles, because the company moves to exploit human wealth and not to share wealth. ${ }^{36}$

\section{THE CRISIS OF STATE SOVEREIGNTY AND THE LOSS OF CONTROL OF NATIONAL WEALTH}

The global dimension of finance has undermined the sovereignty of each State. Moreover, in global times, the exercise of the rights of freedom, as well as of the civil and political rights of individuals is troubled, and social rights become unsustainable. ${ }^{37}$ Georg Henrik von Wright (1916-2003)

35 BECK 1999, 24, observes: with globalization the national States are conditioned and connected transversely by transnational actors, by their chances of power, by their orientations, identities and networks.

36 The specificity of the globalization process consists in the empirically detectable extension, density and stability of the networks of regional-global reciprocal relations and their mass media definition, as well as social spaces and their image flows on a cultural, political, financial level, military and economic, BECK 1999, 25.

37 BAUMAN 2002, 30 observes: «Let's think of the famous triad of rights by Thomas Marshall: economic rights are now out of State control, the political rights that States can 
observes 'it seems that the Nation-State is eroding, or perhaps drying up. Erosive forces are transnational'. ${ }^{38}$

Furthermore, these forces would be able to adopt their own legal system, which they produce themselves and which is distinct from that of the States and from the international order. Such legal system is capable of demanding obedience in the same way as the provisions of the State. Francesco Galgano defined the 'new lex mercatoria' as the 'law created by the business class, without the mediation of the legislative power of the States and formed by rules intended to regulate the commercial relations in a uniform way, beyond the political units of the States. that are established within the economic unity of the markets'. 39

Furthermore, some scholars have pointed out that theories focused on the idea of a transnational law capable of regulating trade would not constitute a novelty and would have a theoretical foundation, because, they argue, a global order could develop both based exclusively on the self-regulated transnational activity of private actors and independently of public institutions. ${ }^{40}$

One of the best-known theses, among the attempts aimed at providing theoretical support to this idea, was elaborated by Gunther Teubner who,

offer are strictly limited and compressed within what Pierre Bourdieu has called the unique thought of neoliberalism and the free market without any rules, while social rights are replaced one by one by the individual duty to provide for themselves and be always one step ahead of others».

38 'Transnational forces are largely anonymous and therefore difficult to identify and do not form a unified system or order. They are an agglomeration of systems manipulated by largely 'invisible' actors ... The forces in question have no unity or coordination aimed at a purpose .... The 'market' is not so much determined by an interaction between competing forces that carry out negotiations, as by the pushes and tears of a manipulated demand, by artificially created needs, and by the desire for rapid profits', WRIGHT 1997, 49 ss.

${ }^{39}$ GALGANO 2001.

${ }^{40}$ Bogdandy and DelLavalle 2013, 59-82. 
starting from the conceptual premises of systems theory, identified in the lex mercatoria an autopoietic legal regime suitable for establishing a global economic and self-referential system that would present itself as a 'global law without a State'. ${ }^{41}$

From a more strictly juridical point of view, the core of the tensions generated by globalization is connected to the theme of 'sovereignty'. However, these tensions would not derive from the reciprocal relations between State law, European law, and international law, but from the complex relationship between the different 'worlds' which were formed in the civil societies. Some authors attribute to these different 'worlds' not a political, but an institutional character, for which the expression 'civil constitutions' was coined. ${ }^{42}$ This thesis would seriously question the value of the institutions of international politics, of State politics, as well as those of European politics.

With globalization, the distinction between the internal market and the global market, and more generally between what is internal and what is external to the State, becomes extremely difficult to maintain, with the exception of police control of the territory and of the population.

The idea of globalization also refers to the indeterminate, ungovernable and self-propelling nature of world affairs and suggests the absence of a centre, a command room, a board of directors, or an executive office. Globalization is 'the new world disorder' as Kenneth Jowitt describes it. ${ }^{43}$ World society, in this sense, is not a national mega-company, which contains and cancels all national societies, but a global horizon, characterized by multiplicity and

41 TEUBNER 2012B.

42 TEUBNER 2012A.

43 JOWITT 1992. 
by the lack of integration, which manifests itself only when it is produced and preserved in communication and in action. ${ }^{44}$

Until the recent past, the State was the regulator of the economy and its role was to defend the dynamic balance, while today it works to ensure the balance of the budget. Yesterday's State could afford indebtedness and inflation, as well as monetary devaluation, which could represent a solution to certain problems; today's one must not be too indebted, it must have a stable currency and it must control price growth. ${ }^{45}$ The State is no longer the controller of national wealth but limits itself to ascertaining the poverty of the national economy and is put in difficulty by the effects of globalization. ${ }^{46}$

Thanks to the indiscriminate and unstoppable spread of rules in favour of commercial freedom and above all the freedom of movement of capital and finance, the 'economy' gradually escapes political control. In this context, the meaning of the term 'economy' becomes 'what pertains to the nonpolitical dimension'. What remains of politics should be addressed by the State, but the State cannot touch anything that affects the life of the economy; any step in that direction would provoke an immediate and furious punitive reaction of the world markets. The economic impotence of

44 BECK 1999, 25.

45 'The function most conspicuous for having been dropped by the orthodox state, or torn out of its hands, is the maintenance of 'dynamic balance' which Castoriadis describes as 'approximate equality between the rhythms of the growth of consumption and the elevation of productivity' - the task which led the sovereign states at various times to impose intermittently import or export bans, customs barriers or state-managed Keynesstyle stimulation of internal demand. Any control of such 'dynamic equilibrium' is now beyond the means and indeed beyond the ambitions, of the overwhelming majority of the otherwise sovereign (in the strictly order-policing sense) states', BAUMAN 1998, 65.

46 The only task that the State can carry out and is expected to carry out in the economic field is to ensure the 'balance of the budget', keeping under control the pressures that are exerted locally for more vigorous State interventions in the management of businesses and for the defense of the population from the most sinister consequences of market anarchy. 
the State would once again be highlighted immediately, humiliating the pro tempore governments in office.

Today, Nation-States cannot make ends meet when, in the sphere of their sovereignty, the specific interests of the population prevail. And for this reason, more and more, they are transformed into executors and plenipotentiaries of forces that have no hope of political control. Thanks to the new 'porosity' of all the 'national economies' and the ephemeral, elusive, and non-territorial nature of the space in which they operate, global financial markets impose their own laws and rules on the entire planet. 'Globalization' does nothing but extend the logic of financial markets to all aspects of life'. States do not have sufficient resources or freedom to manoeuvre in order to bear this pressure because there are economic powers that can say: 'a few minutes are enough to bring down businesses and the States themselves'. ${ }^{47}$

This led to the fact that there is no longer a strong sovereignty of the State. Some authors argue that 'there is neither logical nor pragmatic contradiction between the new extraterritoriality of capital (...) and the new proliferation of feeble and impotent States'; indeed, 'they have all, one may say, developed vested interests in 'weak States' - that is, in such States as are weak but nevertheless remain States', because 'weak, quasi-states can be easily reduced to the (useful) role of local police precincts, securing a modicum of order required for the conduct of business, but need not be feared as effective brakes on the global businesses' freedom'. ${ }^{48}$

47 According to the calculations of René Passet, purely speculative currency financial transactions reach the volume of 1,300 billion dollars per day, fifty times greater than the volume of trade and almost equal to the total of 1,500 billion dollars which are the total reserves of all the 'central banks' of the world. 'No State', Passet concludes, 'can therefore resist more than a few days to the speculative pressures of the "markets", PASSET 1997, 26. 48 'Throwing wide open the gate and abandoning any thought of autonomous economic policy is the preliminary condition, and meekly complied with, condition of eligibility for financial assistance from world banks and money market funds. Weak States is precisely 
In summary, there is no contradiction, neither logical nor practical, between the new extraterritoriality of capital - complete in the case of finance, almost complete for trade, and very advanced for industrial production - and the new proliferation of weak sovereign States and powerlessness. Political fragmentation is not a 'stick in the wheels' of the emerging 'world society', because its connections are given by the free flow of information.

For the freedom of movement and the unlimited possibility of pursuing their goals, finance, trade and the global information industry depend on political fragmentation. Having all developed a relevant interest in 'State weakness', i.e. for weak States but nevertheless such as to remain States.

This reconfiguration of the role of the State, obviously, has great consequences on the crisis of internal democracy, which no longer has an effective role in making decisions. In this regard, Claus Offe argues that, instead of asking us what we could do, we should perhaps ask ourselves if there is someone who is able to do it, given that the borders have become permeable, the sovereignties are nominal, the power is anonymous, and its seat remains empty. This process would be connected to the tendency to abandon public law regulation, because public law has long appeared recessive. Not surprisingly, in recent years, we have talked continuously about deregulation. Offe still says that the dominant feature today is to release the brakes, 'deregulation, liberalization, flexibility, increasing fluidity, simplification of transactions on the financial, real estate and labour markets, reduction of tax burdens, etc. ${ }^{49}$

The affirmation of this sort of 'weak State' should ease us: finally, we have more freedom and less authority, but in reality, such a situation worries us, because freedom is not conceivable without public law.

what the New World Order (...) needs to sustain and reproduce itself, BAUMAN 1998, 6768.

49 OFFE 1996, 37. 
Nation-States, therefore, remain the only forces whose political initiative can be effective. This opens up the controversy between globalization and the State as a political unit. And if, on the one hand, globalization is interpreted as a process to be faced, a sort of 'necessary evil' that we must undergo, ${ }^{50}$ on the other hand, the presence of the State is experienced as the only form that can allow an acceptable coexistence, in the global system. ${ }^{51}$

\section{THE QUESTIONS TO BE ANSWERED AND THE NECESSARY PRESENCE OF THE STATE}

From this point of view, it is necessary to be clear about which questions within the general topic of globalization need to be answered and, on the basis of these questions, to build the institutions that appear most suitable to give an answer.

It is in this context, of course, that 'constitutionalism' can play a decisive role, as a feature proper to the western cultural tradition and as an instrument for the comparison with other cultures. We should consider that, as a result of the processes of globalization, even in the western world, where the institutions of constitutionalism (fundamental rights, division of powers, democracy, and principle of proximity of power) came about, they undergo a distortion. Therefore, there is a loss of sense of the same western tradition represented by rule of law and the decentralized social State. ${ }^{52}$

${ }^{50}$ It is difficult to find an author who exalts globalization in all its aspects, all tend to be critical; yet, no one seems able to hypothesize some measure that blocks or avoids the inconveniences of globalization.

51 STIGLITZ 2001, 94-126.

52 MANGiAMELI 2002, 235-249. 
On the basis of this clarification, however, it is obvious that the questions of globalization are identical in the western, Islamic, and eastern worlds, as well as in the third and fourth worlds, despite the profound and different conditions that exist in these worlds.

The first question to be answered in the global order is that of peace; not only as a condition necessary to build such order itself, but above all because war is an illicit instrument that does not change its nature if there is an end that justifies it. In the international order, ends and means must both be lawful. ${ }^{53}$

The second question concerns fundamental rights, with particular attention to life and individual and group identity.

The third and fundamental question concerns the issue of poverty and the distribution of wealth. ${ }^{54}$

Answering these questions through the State and the tradition of constitutionalism, the only possible institutional form for the protection of fundamental rights, also compels to reconsider the possible policies necessary to build a different world order. In particular, the tradition of constitutionalism, thanks to the (four) principles mentioned above, can be useful to relocate globalization, which is characterized by being really disordered and unequal, in the idea of 'order'.

53 KELSEN 1944.

${ }^{54}$ In this regard, it should not be forgotten that, according to 'the findings of the UN's latest (1998) Human Development Report, that the total wealth of the top 358 'global billionaires' equals the combined incomes of 2.3 billion poorest people ( 45 per cent of the world's population)'; moreover, 'only 22 per cent of global wealth belongs to the so-called 'developing countries', which account for about 80 per cent of the world population' and 'in 1991, 85 per cent of the world's population received only 15 per cent of its income. No wonder that an abysmally meagre 2.3 per cent of global wealth owned by 20 per cent of the poorest countries thirty years ago has fallen by now still further, to 1.4 per cent', see BAUMAN 1998, 70-71. 
In this context, moreover, it can already be noted how for some time it has manifested itself, with the dissolution of the colonial rule, first, and with the dissolution of the reality of the blocs (and of the USSR and Yugoslavia), then, the emergence of a multiplicity of States whose formation took place - sometimes even only on paper - on the basis of the recognition of freedom and democracy.

Finally, the so-called crisis of State sovereignty (understood as an expression of its total autonomy), due to the interconnections and influences determined by the global dimension, not only does not cause the disappearance of the State as guarantor of fundamental rights, but rather must be seen in connection between the State and the international order. Thanks to this connection the governments of the States, by virtue of the tradition of constitutionalism, place the theme of fundamental rights in an order in which individuals in principle would not have their own legal subjectivity. ${ }^{55}$

The problem, therefore, is not the State form in itself, but rather the weakness of the State in the face of the decisions that must be taken in relation to the phenomena of globalization and in front of the possibility that they produce negative effects on the people and not, as it seems desirable (and possible), in their favour.

However, the weakness of sovereign States also appears to be a phenomenon towards which the organizational principles of constitutionalism move effectively, pushing, also from this point of view, to overcome the clear distinction between internal and international order. In fact, the tradition of constitutionalism requires the State to be established according to precise organizational rules, which determine democratic practice, and the decisions are taken as close as possible to the citizens. At the same time, the tradition of constitutionalism also demands that, when

55 See the dating condemnation by the United Nations of apartheid in South Africa (c.b.b., (1964), 846-866). 
the sovereignty of States opens - as many constitutions foresee - towards an international order that 'ensures peace and justice among the nations' (Art. 11 Italian Constitution), the governments of the States give birth to supranational and international institutions of collaboration and promotion of universal principles. ${ }^{56}$

In this perspective, therefore, the very legitimacy of democratic States depends on the ability of public bodies and ruling classes to shape national and foreign policy in accordance to the principles of constitutionalism.

\section{GLOBALIZATION AND EUROPEAN INTEGRATION: THE NEED TO CONSTITUTIONALISE EUROPE}

In this context, the European integration process is at the centre of the relationship between the presence and role of the State and of globalization. The European phenomenon has historically reached a somewhat ambiguous point, as it had been able to move on a double track: in some ways it would amplify the effects of globalization on the economies of the Member States, through the discipline of competition, customs policy, and commercial negotiation with third countries; in other ways, it would raise the question of the resumption of the role of the State, at a supranational level, with a common foreign security and defence policy, as well as cooperation in the field of justice and police, and coordination of social policies.

56 CAPOgRassi 1988, 57-71; BobBio 1979, 129; CASSESE 1988. 
The current phase of the European integration process, therefore, appears uncertain and does not seem entirely capable of fulfilling the issues that emerge from the Member States and from international processes. ${ }^{57}$

In this context, however, the question of the legitimacy of the European legal order becomes decisive. According to the tradition of international organizations, the European system has also found its authority and its capacity for action in the will of the Member States and, in reality, of their respective governments, which have also played the role of legislator in the supranational context. However, this configuration, which was adequate in the case of a very limited community of States and for well-defined areas of competence, is largely insufficient in the case of a larger union, which is also endowed with powers that are as broad as those of the States that compose it. The theory, so dear to the German Federal Constitutional Court, of the European Union as Staatenverbund (association of States) and of European legitimacy anchored in the State's parliaments, which would exercise sufficient powers and control of their respective executives in order to act at European level (Maastricht-Urteil), now appears completely insufficient and in any case not very credible. ${ }^{58}$

Consequently, for the legal order, produced by European law, the issue of the legal nature of the European Union arises concretely, also in light of the realization of the conditions of the rule of law, democracy and the recognition of fundamental rights, according to the provisions of article 2 Treaty on European Union. ${ }^{59}$

${ }^{57}$ Expression of this condition of uncertainty is the White Paper on the future of Europe. Reflections and scenarios for the EU-27 towards 2025, on the occasion of the sixtieth anniversary of the Treaties of Rome (European Commission, COM (2017) 2025 of 1 March 2017).

58 Bundesverfassungsgericht 12 October 1993, Az. 2 BvR 2134, 2159/92. Cf. WINKELMANN 1994.

${ }^{59}$ BLANKe and MANGiameli 2011, 21-46. 
From this point of view, the viable roads appear essentially two and they also appear in opposition: the first would require a restoration of the powers of the individual Member States and, therefore, the idea of not empowering a European constitutional framework would be highlighted; it would culminate in a European policy of removing as many competences as possible at the supranational level, reducing this to the role of mere guarantor of the conditions of the common market. The second way, however, would consist in organizing the European dimension according to the model of constitutionalism to offer a complete constitutional guarantee of fundamental rights and ensure participation of Member States in decision-making processes; it should be based on democratic legitimacy of the legal sources of European law.

The decision to favour the enlargement of the Union up to 28 has prompted the first model, to the detriment of the strengthening of the Union and of its constitutionalisation. ${ }^{60}$ It is no secret that, after the failure of the Constitutional Treaty (Rome 2004), the integration process of the European Union has slowed down and the Lisbon Treaty has, in fact, followed this orientation, creating a condition of mutual tension in the relations between the Union and the Member States: The Union wanted to maintain the competences acquired and the Member States wanted their exercise to be conditioned by the Member States themselves. ${ }^{61}$

Thus, in the midst of the economic crisis, which hit Europe immediately after the entry into force of the Lisbon Treaty, both the European Union and the Member States did not have the ability to remedy the effects of the crisis. Indeed, the European institutions have not been able to implement an anti-cyclical policy, due to the lack of fiscal capacity, but also the Member States, which could have implemented an anti-cyclical fiscal policy, have not been able to implement it due to the European constraints that weighed on

60 BLANKE and MANGIAMELI 2006, 1-20.

61 PERNICE 2010; BLANKE and MANGIAMELI 2011; BIONDI et al 2012. 
national budgets. Thus, a condition of impotence was generated that could overwhelm the entire European system and the single currency; and it is thanks to the European Central Bank if this has not happened. In fact, the ECB, acting as a genuinely federal institution, was able to implement a monetary policy for the defence of the European Union. ${ }^{62}$

This approach, which was at the basis of revanchism during the drafting of the Lisbon Treaty and which expressed various orientations also present in the White Paper on the future of Europe. Reflections and scenarios for the EU-27 towards 2025, on the occasion of the 60th anniversary of the Treaties of Rome, ${ }^{63}$ would, therefore, push all Member States not to surrender further shares of sovereignty without immediate compensations and advantages. The solution that would be offered to the European system would be to consolidate the internal market, abandoning the project of political and constitutional integration.

However, the Union would thus run the risk of becoming a weak subject and, as an element of weak integration, it would become an amplifier of the negative effects of globalization. The most evident aspect of this weakness lies in the choice made at the European level in favour of an institution solely responsible for economic exchange. ${ }^{64}$

In this way, Europe could be an institutionally less invasive presence, as it would not regulate all behaviours nor all the policies, as the State does. However, at the same time, it would be so limiting from an economic point of view, to make the lack of effective protection of fundamental rights and particularly of social rights stand out even more. Globalization and European governance would end up interacting, producing an effect of amplification of the limits that the globalized economy generates from a social and political point of view. A real reduction of the sphere of rights,

62 MANGIAMELI 2016, 11-58.

${ }^{63}$ European Commission, COM (2017) 2025 of 1March 2017.

64 WEBBER 2014, 341-365. 
in fact, generates social insecurity and reduces solidarity, while from a political point of view it worsens the possibilities of participation of the citizens and restricts democracy to mere electoral formalism. ${ }^{65}$

If we consider this perspective seriously, the European States that have constituted the European legal system cannot help but concretely ask themselves how to fill a void that is gradually developing in the European integration process.

In this perspective, therefore, the second way indicated above, linked to the constitutional organization of the European dimension according to the principle of the protection of fundamental rights and the division of powers, appears, even if politically more complex, as more appropriate to the reality of the problems posed by globalization, and more capable to ensure participation of the Member States in the decision-making processes, as well as furnishing the basis of a democratic legitimation of the sources of law, and developing the idea that the Union acts in accordance with the 'rule of law'. ${ }^{66}$ This perspective appears more coherent, not only with the problems posed by globalization, but also with those that emerge historically from the process of European integration, and is able to respond in a qualitatively different way to the questions of the States and citizens of the Union. ${ }^{67}$

An evolution of this kind, difficult for national States with a tradition anchored in the myth of sovereignty, should coincide with a conscious constitutionalisation of the supranational dimension and with political integration, which could require further transfers of powers by the Member States. ${ }^{68}$

${ }^{65}$ For a detailed examination of the problems, see MANGIAMELI 2013.

${ }^{66}$ European Court of Justice, 23 April 1986, case 294/83, Les Verts/Parliament, Racc., 1986. Cf. also Opinion 14 December 1991, Racc., 1991, I-6079, pt. 19.

${ }^{67}$ ISIKSEL 2016.

68 Pribán 2015; Mangiameli 2017, 189-216. 
Indeed, in the years of the crisis there has also been a reflection in this regard. Just think of the Commission proposal, made known at the end of November 2012, with the document entitled: A blueprint for a deep and genuine economic and monetary union. Launching a European Debate. ${ }^{69}$

Such document is truly important because it shows a clear perception by the Commission that the European Union must be reformed to continue to exist and must become more democratic and politically more significant than the Nation-States that support it. The other European institutions, which, in recent years, have developed their responses to the crisis, have also developed the same conviction that a reform of the European institutional system is necessary. Indeed, the solution would go in the direction of a strengthening, not only of the currency, social cohesion and European economic policy, but also of the fiscal policy, with the autonomy of the European budget, and democratic control, capable of giving full legitimacy to European law, and accompanied by the institutional strengthening of the European system. ${ }^{70}$ The changes hypothesized to adapt the European Treaties to the degree of financial responsibility ("further sharing of the financial prerogatives presupposes a commensurate political integration'), which is required of the European institutions are consciously anchored to the transfer of sovereignty from the Member States ("the level of democratic responsibility must remain commensurate with the degree of transfer of sovereignty from the Member States to the European Union'), and to the attribution of 'responsibility at the level at which the executive decision concerned is taken, taking due account also of the level on which it affects the decision'. This means that, if a decision is of European responsibility, it is up to the Institutions, but, if it is reflected on the Member States, it cannot fail to consider the opinion of each of them on that specific

69 European Commission, A blueprint for a deep and genuine economic and monetary union. Launching a European Debate, COM (2012) 777 final/2, Brussels, 30.11.2012.

${ }^{70}$ See to this effect the Report of the five Presidents, Completing Europe's Economic and Monetary Union (22 June 2015). 
decision. Furthermore, the conditions for a European (budgetary) fiscal policy financed with 'own resources' deriving from a European taxation and the creation 'of a structure similar to a "Treasury" of the Economic and Monetary Union in the Commission' are affirmed, in order to 'give political direction and increase democratic accountability', so that the Union is placed in a position to resist potential future economic shocks. It follows that, in view of the reform, first of all, 'the European Parliament has the primary role of guaranteeing the democratic legitimacy of all decisions taken at Union level, in particular by the Commission'.

However, the limit of the entire project would be given by the timing with which it would be intended to be carried out. In fact, this would be divided into three time periods: the first would be based on the strengthening of the surveillance policy in place (1 July 2015 - 30 June 2017); the second would concern the possibility of creating a true autonomous tax capacity of the EMU to support the implementation of the political choices deriving from greater coordination (over a five-year horizon); finally, the third, more longterm (by 2025), would envisage the realization of 'an adequate sharing of sovereignty, responsibility and solidarity at the European level', and the formation of 'an autonomous euro area budget'.

This approach, which subordinates the political process of integration and constitutionalisation of the European Union to economic constraints and budgetary policies, hides the evident purpose of postponing the revision of the European Treaties (of the Lisbon Treaty). Thus, shifting ahead the democratization of the European order, it leaves the supranational democracy, only as a long-term goal stated on paper. ${ }^{71}$

But the uncertainties resulting from the effects of the long economic crisis and the difficulties existing for a modification of the current European

71 Thus, HABERMAS 2013, which also underlines the strategic role of such a plan for European technocracy, which would continue to strengthen and escape democratic control. 
Treaties can only constitute a temporary obstacle to the constitutionalisation of Europe, which will probably require longer implementation times. However, these difficulties won't be able to determine the abandonment of the perspective of political integration, since this is the only perspective that, with adequately shaped European institutions can guarantee, on the one hand, the realization of the fundamental rights of European citizens and the growth of forms of protection and, on the other hand, the cooperation between the people of Europe, respecting the constitutional autonomy of the Member States. ${ }^{72}$

\section{THE CONSTITUTIONALIZATION OF INTERNATIONAL PROCESSES}

Globalization requires that even the internationalized economy is guaranteed by law and that there are international institutions capable of verifying that the rules of the global market are not violated. However, the global order tends to appear as an anonymous order, where the forces that exercise economic dominion over human beings appear elusive. Even the international institutions (Monetary Fund, World Bank, World Trade Organisation, Organisation for Economic Co-operation and Development, etc.) appear to be deprived of every political capacity and present themselves almost as technical executors of a system apparently without representatives.

The question of knowledge and publicity of political power begins within the States, where, first of all, arises the need for a power with a knowable 'face', in order to address the issues of the traceability of command and of

72 MANGiameli 2016, 11-58. 
the respect for economic rules. The first aspect, connected to the tolerability of power, requires that the theme of democracy within the States, including those 'liberated', be addressed not in a formal way, as a celebration of the electoral rite, ${ }^{73}$ but always in connection to the pre-eminence of the person, i.e. as a substance of public decision making, which is compatible with the recognition of fundamental rights and is, also, placed at the service of their protection. The second element, which is accompanied by the publicity of the economic choices and by the commitment strategies on some aspects (for example, the mode of production and the place of production or, above all, the use of scientific research), must connect the market with some political and economic factors, such as, for example, the evaluation of the rating of companies, also in relation to social actions and the transparency of policies, and must consider the effectiveness of the sanctioning system for the abuse of dominant positions.

However, the question of knowledge and publicity of power, both on the political and on the economic side, does not appear confined within the borders of the States, but needs to be extended to international law, and this has involved and still involves, in this area, the principles of constitutionalism, ${ }^{74}$ to the point of advocating a 'global constitutional law', consisting of 'a subset of international rules and principles, which are so important that they deserve the label 'constitutional'. ${ }^{75}$

73 Crouch 2005.

${ }^{74}$ KUmm 2004, 907-931; BOGDANDY 2006, 223-242; KNAUFF 2008, 68. 453-490; SwEET 2009, 621-645; BogdANDY and VENZKE 2010, 1-49; HABERMAS 2012, 1-44; CAPALDO 2014, 230-255.

75 With the caveat that Whether these norms (rules and principles) of potential constitutional quality are superior to ordinary international norms; whether they are created by States or by other actors as well; whether they are always "hard" legal norms; whether they embody a specific set of material principles; and whether they are 'constitutional' only to the extent that they are enforceable by some form of judicial review, remains to be seen', Peters and Armingeon 2009, 385-395; Peters 2009, 397-411; Peters 2017, 331-335. 
International law, in its origin, was not an order that included all the entities that were in fact able to exercise forms of supremacy in a territorially defined way, but required the existence of a substrate, namely the participation in certain principles and recognition by the community of States. ${ }^{76}$ According to this logic, sovereignty was connected to a juridical dimension, which transcended sovereignty itself and whose exercise found justification (and limits) only in the context of the principles which inspired the juridical dimension of international law.

Over time, with the affirmation of the principles of positivism, these elements were obfuscated, and international subjectivity was recognized to any territorial authority, provided it was effective. In this way, State sovereignty is increasingly understood as a pure factual situation that legitimizes itself, without any connection even in the internal order to the position of the individual.

Thus, international law was deprived of any founding legal reference and reduced to a mere instrument of coordination between States, in which absolutely prevailed the rule that, in international law, in the end, only the will of the States is decisive and there is no possibility of constraints through higher values.

The expression 'global constitutionalism' would characterize 'an academic and political agenda which identifies and advocates the application of constitutionalist principles, such as the rule of law, checks and balances, human rights protection, and possibly democracy, in the international legal sphere in order to improve the effectiveness and the fairness of the international legal order. Therefore, global constitutionalism has both descriptive and prescriptive elements. It does not merely claim to describe some features of the status quo of international relations, but also seeks to provide arguments for their further development in a specific direction'.

${ }^{76}$ In this regard, see the thought of Francisco de Vitoria and Francisco Suárez on the principles of international law, see PALAMIDESSI 2010, 94-112; BARBERINI 2012; BRANDÃO 2014, 1-14. 
The two world conflicts with their catastrophes, however, have overshadowed this way of understanding international law, which had led to the distorted use of force by the State, both internally and externally. With the end of the Second World War, in particular, an international law based on a state-centric conception and on an absolute vision of the sovereignty of States is criticized; and this is the vehicle to introduce forms of constitutionalisation into international processes, for which 'the individual, and not the State, must be - from now on - the subject and the central moral unity of international law' ${ }^{77}$

Although the will of States, as an instrument of action of international law, cannot be ignored, democratic principles, the rule of law, and human rights are progressively observed as the prerequisites for the recognition of States in international law. ${ }^{78}$ From this point of view, the practice of considering the dismissal of a democratically chosen government as a danger to peace by the United Nations Security Council, appears to confirm the rising constitutionalisation of the international order.

The principles of constitutionalism, in international law, essentially produce two effects: on the one hand, they lead to a different conception of the use of force, and, on the other hand, they promote an international structure, where, thanks to the emergence of rights, we are witnessing the formation of regional safeguard structures and systems that increasingly permeate relations between States.

${ }^{77}$ HALTERN 2003, 541.

${ }^{78}$ Article 25 of the International Covenant on Civil and Political Rights states: 'Every citizen shall have the right and the opportunity, without any of the distinctions mentioned in article 2 and without unreasonable restrictions: (a) To take part in the conduct of public affairs, directly or through freely chosen representatives; (b) To vote and to be elected at genuine periodic elections which shall be by universal and equal suffrage and shall be held by secret ballot, guaranteeing the free expression of the will of the electors; (c) To have access, on general terms of equality, to public service in his country.' 
With reference to the first aspect, the main codification of the principle of force refusal is found in article $2, \mathrm{n}^{\circ} 4$ of the United Nations Charter, according to which 'all Members shall refrain in their international relations from the threat or use of force against the territorial integrity or political independence of any State, or in any other manner inconsistent with the Purposes of the United Nations', while in art. 51 we can find 'the inherent right of individual or collective self-defence if an armed attack occurs against a Member of the United Nations' and, above all, the principle that the Security Council has the competence to take 'the measures necessary to maintain the international peace and security', ${ }^{79}$ in the event of their violation and with the tools that Chapter VII of the Charter itself governs.

The attribution of the task of maintaining international peace and security to an authority, agreed by the States, represents a formative element of the constitutionalisation process of international law, which, although deeply imperfect, and often dysfunctional, represents an evolution that is not easily reversible. Therefore, it can be said that, according to international law, the use of force does not qualify itself for the results it actually realizes, but it is subject to an evaluation according to principles that go beyond the will of the single State. Moreover, in the recent past these principles have also found their application in the internal side of States, thus defining a different efficacy of the old principle of non-interference in the internal affairs of a State, which the Charter precisely accepts without prejudice to the 'application of coercive measures under chapter VII' (art. 2, $\mathrm{n}^{\circ} 7$ ).

The other side of the process of constitutionalisation of the international order is represented by the multiple acknowledgments of individuals' rights

${ }^{79}$ For these reasons, the second part of the same provision provides that 'measures taken by Members in the exercise of this right of self-defence shall be immediately reported to the Security Council and shall not in any way affect the authority and responsibility of the Security Council under the present Charter to take at any time such action as it deems necessary in order to maintain or restore international peace and security'. 
towards States that transcend domestic law and are expressions, both of general acts of international law (Universal Declaration of Human Rights 1948; European Convention on Human Rights 1950; International Covenant on Civil and Political Rights 1966), as well as sectorial acts that may concern economic, social and environmental issues (the International Whale Commission; the Food and Agriculture Organization, and the World Health Organization; and also the UN Convention on the Law of the Sea and the Convention on the Protection of the Environment). ${ }^{80}$

Additionally, the States in the field of international law are making commitments to implement universal principles on the political, military, economic and social side (for example, the ten principles of the Helsinki Final Act of 1975; the Charter of Paris in 1990; the Anti-Personnel Mines Convention); they create judging authorities to which they submit, for specific cases, sometimes even of a certain magnitude, as in the case of the Rome Statute on the International Criminal Court (1998-99), and, more generally, they disseminate various agreements, conventions, treaties, etc., of dispute settlement mechanisms.

This process of constitutionalisation that has affected the international community, has also had consequences of a structural nature for its ordering, the formation of which no longer appears simply linked to the willpower of States. In fact, the norms of international law which condition the behaviour of States, are not only those produced by the States themselves, but on the contrary there are norms which compel some States without their participation, and which are - in one way or another - the expression of a standard (international practice, fundamental principles recognized by 'civilized nations', etc.).

This means that, even in the context of international law, there is a link between the recognition of rights to individuals and law production, which

80 HELD 1995. 
begins to be governed by a principle of hierarchy of the legal sources. In this context, moreover, what is called international forms of constitutional aid $^{\prime 81}$ appear, thanks to which the international community, through forms of multilateral pressure, gradually manages to insure, in situations of crisis, the democratic development and recognition of fundamental rights within States. ${ }^{82}$

What has been said so far shows that there is a significant tension between globalization and constitutionalism, and they both move transversely within the States and within the international community.

This tension can find a useful balance point, distributing advantages and limiting negative effects on social systems around the world, provided that the States react in a coordinated and supportive way. What is required, is that they apply the principle of collaboration; especially, because the coordination of solidarity seems possible, as, indeed, individuals and nations discover that they have more and more interests in common. ${ }^{83}$

81 See FROWEIN 2000, 427-447.

82 This particular area must also include the particular (European) form of constitutional aid represented by the Lomé Convention, thanks to which the African, Caribbean and Pacific countries (78 countries in total) maintain stable relations with the European Union and have established a close, deep and complex partnership. Cooperation, in particular, is articulated around two main poles: economic and commercial cooperation and development cooperation. But what is most important is that in its most recent form the last Lomé convention, that of Lomé IV, signed in 1989 for a duration of 10 years, introduced, among the numerous innovations, the promotion of human rights and respect of democracy, as key elements of this partnership, and, moreover, new objectives have been included in the cooperation, such as enhancing the role of women and protecting the environment. Another important innovation was the so-called decentralized cooperation, expressed by the participation in the development process of other actors, such as civil society.

83 See SCHWARZENBERGER 1962; FrIEDMANN 1964; DupuY 1998, 9. 278-286; RAustiala 2002; MingST and ARrEGuíN-TOFT 2018. 
Constitutionalism can serve to build an internal and international order capable of supporting this collaboration. It can be the measure that allows to build territorial areas capable of adequately supporting the population living within it, by guaranteeing a comparable standard of civil life. Local systems, which are measured according to this unit of judgment, would fully implement the principle of autonomy because they don't only appear capable of ensuring acceptable living conditions, but also, and above all, because they allow all the profiles that characterize identities to be preserved. The local systems would thus be in a position to be an active factor of the global order. ${ }^{84}$ Moreover, on the international side, it can make it possible to replace the realities of 'globalization' with the reality of 'universalization'; this concept contained hope, intention, and determination in order to create a reasonable, just and, above all, human order; a unique order, respectful of the many differences and identities that the earth has shaped. ${ }^{85}$

84 MANGIAMELI 2013.

85 According to the principles expressed by KANT 2011; see also KOSKENNIEMI 2007, 936. 


\section{REFERENCES}

ACKermann, Bruce, "The New Separation of Powers", Harvard Law Review, 2000, 633-725.

Amato Mangiameli, Agata C., Stati post-moderni e diritto dei popoli, Turin, 2004.

BARBERINI, Giovanni, "Principi di diritto internazionale nella teologia cattolica", Stato, Chiese e pluralismo confessionale, 2012.

Bauman, Zygmunt, Globalization: The Human Consequences, New York, 1998.

BAUMAN, Zygmunt, Intervista sullidentità, Laterza, Rome-Bari, 2002.

BEAUD, Olivier, "Constitution et constitutionnalisme", in: Philippe Raynaud and Stéphane Rials (eds.), Dictionnaire de Philosophie Politique, Paris, 2003, 118.

BECK, Ulrich, Che cos'è la globalizarazione, Rome, 1999.

Biondi, Andrea, EECKHOUT, Piet and RiPley, Stefanie (eds.), EU Law after Lisbon, Oxford, 2012.

BlANKE, Hermann-Josef and MANGIAMELI, Stelio, Governing Europe under a Constitution. The Hard Road from the European Treaties to the European Constitutional Treaty, Berlin-Heidelberg-New York, 2006.

Blanke, Hermann-Josef and MANGIAMELI, Stelio, European Union after Lisbon, Heidelberg, 2011.

BOBBIO, Norberto, Il problema della guerra e le vie della pace, Bologna, 1979.

BOGDANDY, Armin von, "Constitutionalism in International Law: Comment on a Proposal from Germany", Harvard International Law Journal, 2006, 223-242.

BOGDANDY, Armin von and VENZKE, Ingo, "Zur Herrschaft internationaler Gerichte: Eine Untersuchung internationaler öffentlicher 
Gewalt und ihrer demokratischen Rechtfertigung”, Zeitschrift für ausländisches öffentliches Recht und Völkerrecht, 2010, 1-49.

Bogdandy, Armin von and Dellavalle, Sergio, "The Lex Mercatoria of Systems Theory: Localisation, Reconstruction and Criticism from a Public Law Perspective”, Transnational Legal Theory, 2013, 59-82, https://doi.org/10.5235/20414005.4.1.59.

Brandão, Cláudio (ed.), Direitos Humanos e Fundamentais em Perspectiva, São Paulo, 2014.

CAPOGRASSI, Giuseppe, La Dichiarazione universale dei diritti dell'uomo e il suo significato, Milan, 1988.

CASPER, Gerhard, "Constitutionalism", in: Leonard W. LEVY and Kenneth L. KARST (eds.), Encyclopedia of the American Constitution, New York, 1986, 633-640.

CASSESE, Antonio, I diritti umani nel mondo contemporaneo, Rome-Bari, 1988.

ChabOD, Federico, Storia dell'idea d'Europa, Bari, 1961.

Craig, Paul, The Lisbon Treaty, Oxford, 2010.

CRISAFulLI, Vezio, Lezioni di diritto costituqionale, Padua, 1970.

Crouch, Colin, Postdemocrazia, Rome-Bari, 2005.

DE RosA, Luigi, La crisi economica del 1929, Florence, 1979.

DupuY, Pierre-Marie, "International Law: Torn between Coexistence, Cooperation and Globalization. General Conclusions", European Journal of International Law, 1998, 278-286, https://doi.org/10.1093/ ejil/9.2.278.

Elster, Jon and Slagstad, Rune (eds.), Constitutionalism and Democracy, Cambridge, 1988.

Esposito, Carlo, Commento all'Articolo 1 della Costiturione: La Costiturione italiana. Saggi, Padua, 1954. 
FRIEDMANN, Wolfgang, The Changing Structure of International Law, New York, 1964.

FROWEIN, Jochen, "Konstitutionalisierung des Völkerrechts", in: Klaus DICKE et al. (eds.), Völkerrecht und internationales Privatrecht in einem sich globalisierenden internationalen System: Auswirkungen der Entstaatlichung transnationaler Rechtsbeziehungen, Heidelberg, 2000, 427-448.

GALGANO, Francesco, Le Istiturioni dell'economia capitalistica, Bologna, 1974.

Galgano, Francesco, Lex Mercatoria, Bologna, 2001.

GoldschmidT, Nils, Wirtschaft, Politik und Freibeit: Freiburger Wirtschaftswissenschaftler und der Widerstand, Tübingen, 2005.

HABERMAS, Jürgen, “Die Krise der Europäischen Union im Lichte einer Konstitutionalisierung des Völkerrechts. Ein Essay zur Verfassung Europas", Zeitschrift für ausländisches öffentliches Recht und Völkerrecht, 2012, 144.

Habermas, Jürgen, Democracy, Solidarity and the European Crisis, Lecture delivered 26 April 2013, Leuven, 2013.

HALTERN, Ulrich, "Internationales Verfassungsrecht? Anmerkungen zu einer kopernikanischen Wende”, Archiv des öffentlichen Rechts, 2003, 511-557.

Hamilton, Alexander, MAdison, James and JAy, John, The Federalist Papers, New York, 1982.

Hamilton, Walton H., “Constitutionalism”, in: Erwin R.A. Seligman (ed.), Encyclopedia of the Social Sciences, Vol. IV, New York, 1937.

HAYEK, Friedrich, "The Economic Conditions of Interstate Federalism”, New Commonwealth Quarterly, 1939, 131-149.

HeLD, David, Democracy and Global Order. From the Modern State to the Cosmopolitan Governance, Cambridge, 1995. 
Hesse, Konrad, Der unitarische Bundesstaat, Karlsruhe, 1962.

IsIKSEL, Turkuler, Europe's Functional Constitution. A Theory of Constitutionalism Beyond the State, Oxford, 2016.

JeLLINEK, Georg, Allgemeine Staatslehre, Berlin, 1922.

JowITT, Ken, The New World Disorder: The Leninist Extinction, Berkeley-Los Angeles, 1992.

KAISER, Joseph H., Die Repräsentation organisierter Interessen, Berlin, 1956.

KANT, Immanuel, Zum ewigen Frieden. Ein philosophischer Entwurf, Berlin, 2011.

Kelsen, Hans, Die Verfassungsgesetze der Republik Deutschösterreich: mit einer bistorischen Übersicht und kritischen Erläuterungen, Vol. I, Wien-Leipzig, 1920.

KELSEN, Hans, Österreichisches Staatsrecht: Ein Grundriss entwicklungsgeschicbtlich dargestellt, Tübingen, 1923.

Kelsen, Hans, Peace through Law, Chapel Hill, 1944.

KEYNES, John Maynard, The General Theory of Employment, Interest and Money, London 1936.

KNAUFF, Matthias, "Konstitutionalisierung im inner- und uberstaatlichen Recht. Konvergenz oder Divergenz", Zeitschrift für ausländisches öffentliches Recht und Völkerrecht, 2008, 453-490.

KosKenniemi, Martti, "Constitutionalism as Mindset: Reflections on Kantian Themes About International Law and Globalization", Theoretical Inquiries in Law, 2007, 9-36.

Kumm, Mattias, "The Legitimacy of International Law: A Constitutionalist Framework of Analysis", The European Journal of International Law, 2004, $907-$ 931. 
MangIAMELI, Stelio, Diritto costituzionale e integraquione europea, Milan, 2001. Mangiameli, Stelio, “Appunti sullo Stato sociale sussidiario”, Teoria del Diritto e dello Stato, 2002, 235-249.

MANGIAMELI, Stelio, "Crisi economica e distribuzione territoriale del potere politico”. Relazione al XXVIII Convegno annuale dell'AIC, www.rivistaaic.it, 2013.

MANGIAMELI, Stelio, "Il sistema europeo: dal diritto internazionale al diritto costituzionale e ritorno?”, Diritto e Società, 2016, 11-58.

Mangiameli, Stelio (ed.), The Consequences of the Crisis on European Integration and on Member States. The European Governance between Lisbon and Fiscal Compact, Heidelberg, 2017.

MANSFIELD, Harvey C. Jr., "Constitutionalism and the Rule of Law", Harvard Journal of Law and Public Policy, 1985, 323-326.

MATTEUCCI, Nicola, Organizzazione del potere e libertà. Storia del costituzionalismo moderno, Torino, 1976.

MAYER, Otto von, Deutsches Verwaltungsrecht, Vol. I, Leipzig, 1895.

McIlwain, Charles Howard, Constitutionalism, Ancient and Modern, Ithaca (NY), 1947.

Mingst, Karen A. and ArreguíN-TOFT, Ivan M., Essentials of International Relations, New York-London, 2018.

Mortati, Costantino, Istituzioni di Diritto Pubblico, Padua, 1976.

OfFE, Claus, Modernity and the State: East, West, Cambridge, 1996.

PALAMIDESSI, Andrea Maria, Alle origini del diritto internazionale. Il contributo di Vitoria e Suàrez alla moderna dottrina internazionalistica, Rome, 2010.

PASSET, René, “Ces promesses des technologies de l'immatériel”, Le Monde diplomatique, July 1997, 26-27. 
PERNICE, Ingolf, Der Vertrag von Lissabon: Reform de EU obne Verfasung?, Baden Baden, 2008.

PETERs, Anne, “The Merits of Global Constitutionalism”, Indiana Journal of Global Legal Studies, 2009, Art. 2.

Peters, Anne, "Foreign Relations Law and Global Constitutionalism", American Journal of International Law, 2017, 331-335, https://doi.org/10.1017/aju.2017.90.

PETERS, Anne and Armingeon, Klaus, "Introduction-Global Constitutionalism from an Interdisciplinary Perspective", Indiana Journal of Global Legal Studies, 2009, Art. 1.

PigOU, Arthur Cecil, The Economics of Welfare, London, 1932.

PIRIS, Jean-Claude, The Lisbon Treaty, Cambridge, 2010.

PREUSs, Ulrich, “Constitutionalism”, in: E. Craig (ed.), Routledge Encyclopedia of Philosophy, Vol. II, London-New York, 1998.

PRIBÁN, Jiri, Sovereignty in Post-Sovereign Society. A System Theory of European Constitutionalism, Surrey-Burlington, 2015.

RAustialA, Kal, "The Architecture of International Cooperation: Transgovernmental Networks and the Future of International Law", Virginia Journal of International Law, 2002, 1-92.

RITTER, Joachim et al. (eds.), Historisches Wörterbuch der Philosophie, BaselStuttgart, 1989.

Romano, Santi, Scritti minori, Vol. II, Milan, 1950.

SARTORI, Giovanni, Democrazia e definizioni, Bologna, 1957.

SARTORI, Giovanni, Democrazia. Cosa è, Milan, 1993.

SCHMITT, Carl, Verfassungslehre, Berlin, 1928. 
SCHWARZENBERGER, Georg, The Frontiers of International Law, London, 1962.

STIGLITZ, Joseph, "Redefining the role of the State. What should it do? How should it do it? And how should these decisions be made?", Ha-Joon CHANG et al. (eds.), Joseph Stiglitz and the World Bank: The Rebel Within, London, 2001, 94-126.

STONE SWEET, Alec, "Constitutionalism, Legal Pluralism, and International Regimes”, Indiana Journal of Global Legal Studies, 2009, 621-645.

TEuBnER, Gunther, "Das Projekt der Verfassungssoziologie: Irritationen des nationalstaatlichen Konstitutionalismus", Zeitschrift für Rechtssoziologie, 2012a, 189-204.

Teubner, Gunther, Constitutional Fragments. Societal Constitutionalism and Globalization, Oxford, 2012b.

VATIERO, Massimiliano, "The Ordoliberal Notion of Market Power: An Institutionalist Reassessment", European Competition Journal, 2010, 689-707, https://doi.org/10.5235/ecj.v6n3.689.

VILE, M.J.C., Constitutionalism and the Separation of Powers, London, 1967.

WeBBER, Douglas, "How likely is it that the European Union will disintegrate? A critical analysis of competing theoretical perspectives", European Journal of International Relations, 2014, https://doi.org/10.1177/1354066112461286.

WHEARE, Kenneth Clinton, Modern Constitutions, London, 1951.

WinkELMANN, Ingo (ed.), Das Maastricht-Urteil des Bundesverfassungsgerichts vom 12. Oktober 1993. Dokumentation des Verfahrens mit Einführung, Berlin, 1994.

Wormuth, Francis D., The Origins of Modern Constitutionalism, New York, 1949. 
Wright, G.H. von, "The Crisis of social Science and the Withering Away of the Nation State", Associations, 1997, 49-52.

Zangara, Vincenzo, "Lo Stato di diritto in evoluzione", Diritto e società, 1983, 193-252.

ZicCARDi CAPALDO, Giuliana (ed.), The Global Community. Yearbook for International Law and Jurisprudence, Oxford, 2014. 